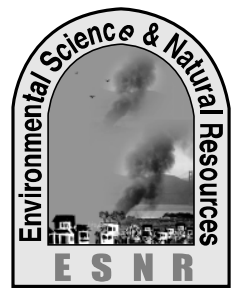

\title{
Comparative Study on the Dahi-prepared from Whole Milk, Skim Milk, Reconstituted Milk and Recombined Milk
}

\author{
M. R. Uddin ${ }^{1}$, M. A. Mazed ${ }^{1}$, M. S. Islam ${ }^{2}$, N. Hassan ${ }^{1}$ and M. A. S. Khan ${ }^{1}$ \\ ${ }^{1}$ Dept. of Dairy Science, Bangladesh Agricultural University, Mymensingh. \\ ${ }^{2}$ Agrotechnology Discipline, Khulna University, Khulna.
}

\begin{abstract}
Dahi was prepared from whole milk, skim milk, reconstituted and combined milk by adding $12 \%$ sugar to each type and then these milks were boiled to reduce the volume by $30 \%$. After adding 3\% starter culture all these dahi mix were incubat ed at $40^{\circ} \mathrm{C}$ for $4-5$ hours. Then all the dahi samples were kept in the refrigerator at $4{ }^{\circ} \mathrm{C}$ for at least 2 hours. All these types of dahi were judged by a panel of expert judges to determine the physical qualities. Chemical and microbiological tests were also car ried out to determine the composition and qualities. Whole milk dahi was the best for overall acceptability followed by skim milk dahi but other two types were somewhat less acceptable. There was a significant difference $(\mathrm{P}<0.01)$ among the overall scores obtained. There were a significant difference $(\mathrm{P}<0.01)$ in percent acidity, for all the samples \% DM, \% fat, \% protein and \% ash showed a non significant difference. For all the chemical qualities, dahi from whole milk ranked the highest followed by others types. Among the microbial qualities, total viable counts were higher in all the sample, though there was a significant difference $(\mathrm{P}<0.05)$. Yeast and mold counts differed significantly $(\mathrm{P}<0.01)$, although the counts were lower. Although, dahi prepared from reconstituted and recombined milk were not as good as that from whole milk, there is a great prospect to improve the qualities.
\end{abstract}

Key words: Comperison, Dahi, Reconstituted milk, Recombined milk, Skim milk, Whole milk

\section{Introduction}

Milk is termed as nearly or almost perfect food, there are many types of milk products produced in different countries of the world. In Bangladesh milk is used to manufacture sweet, butter, ghee, chocolate, Dahi, Ice-cream as commercial basis. The most popular and widely accepted item among the milk products is the dahi. In our country, yogurt/dahi is a very common article of diet. These dairy products are delicious and wholesome and very nutritious. In this era of industrialization, food habit of common people is changing as they are growing more health conscious. As a result, milk is converted to various milk products, primarily to fermented ones, dahi is one of them. In our neighboring country India, about 7\% of the total milk produced is converted to dahi for consumption whereas in Pakistan it is 4\% (Chakraborty, 1998). About 4\% of the total milk produced in Bangladesh is used for the preparation of dahi (Mustafa, 1997).

In Bangladesh and some other countries yogurt/dahi is usually made from fresh whole milk or mixing powdered milk with whole milk. It has been established that best quality of yogurt depends on the presence of streptococci and lactobacilli on the ratio of 1:1 (Stocklin, 1969). Dahi and yogurt is popular fermented milk product noted for their typical flavor, characteristic semi-solid consistency and high therapeutic value. As a result there is a considerable increase in the popularity of dahi and yogurt in all parts of the world. Some research works have been performed in different countries on the quality of dahi prepared from whole milk and skim milk (Murtaza, 1998; Mostafa, 1997; Nahar,
2002; Rahman, 1998 and Sarker et al., 1996). No research findings have not been available in our country on the quality of dahi made from reconstituted and recombined milk. Hence an attempt was made to judge the quality of dahi prepared from reconstituted and recombined milk. Dahi is a nutritional milk product and it is not easily available at a reasonable cost throughout the year because its raw material milk is not produced at the same level in al the season of our country. But dahi prepared recombined and reconstituted milk are easily available round the year and it will be under our peoples buying capacity. So this experiment is very important from practical point of view. Considering the above stated fact, the study has undertaken to find out the feasibility of using reconstituted and recombined milk in preparing dahi and to access the quality of dahi prepared from different forms of cow milk (whole milk, skim milk, powdered skim milk with added milk fat).

\section{Materials and Methods}

This experiment was carried out at the Laboratory of Dairy Science of Bangladesh Agricultural University, Mymensingh for preparation of dahi from whole milk, skim milk with added cream fat, reconstituted milk and recombined milk. Whole milk was collected from Bangladesh Agricultural University (BAU), Dairy Farm, Mymensingh and non-fat-dry milk powder was collected from local market with the brand name 'Prolene' the NewZealand food Bangladesh Ltd. Dhaka. 


\section{Preparation of whole milk dahi}

Collected $1000 \mathrm{~g}$ whole milk sample was heated to boiling temperature and the volume was reduced by $30 \%$ when the milk reached the boiling point sugar was added at the rate of 12 per cent and the milk was stirred thoroughly with the help of stirrer. When the desired volume was reached, milk pan was taken out from the heater and allowed to cool down at 42$45^{\circ} \mathrm{C}$. Starter culture was added at the rate of $3 \%$. After inoculation, warm milk of $42^{\circ} \mathrm{C}$ was kept undisturbed in the incubator at an incubation period temperature of $37^{\circ} \mathrm{C}$ until complete coagulation (Akter et al., 2010). It took 4-5 hours for the coagulation. The dahi samples were taken out from the incubator and stored in a refrigerator at about $4^{\circ} \mathrm{C}$ for at least 2 hours and then served.

\section{Preparation of added cream skim milk dahi}

Added cream skim milk dahi was prepared by dissolving 930g skim milk and $70 \mathrm{~g}$ heavy cream having $50 \%$ fat was also added then dahi was prepared in the same method followed for whole milk dahi.

\section{Preparation of reconstituted milk dahi}

Reconstituted or re-hydrated milk refers to milk prepared by dispersing whole milk powder in water approximately in the proportion of one part powder to $7-8$ parts of water (DMMPS - 14). Reconstituted milk was prepared by dissolving $200 \mathrm{~g}$ 'full cream powder' with $800 \mathrm{ml}$ water. Then dahi was prepared in the same method followed for whole milk dahi.

\section{Preparation of recombined milk dahi}

Recombined milk refers to product obtained when butter oil, skim milk powder and water are combined in the correct proportion to yield fluid milk. Instead of butter oil other milk fat sources like unsalted butter or plastic cream can be used (DMMPS - 14). Recombined milk was prepared by dissolving $100 \mathrm{~g}$ skim milk powder in $830 \mathrm{ml}$ water and $70 \mathrm{~g}$ heavy cream having $50 \%$ fat was also added. Then dahi was prepared in the same method followed for whole milk dahi. Then all the samples were judged by a team of expert judge for organoleptic evaluation.

\section{Chemical analyses (Milk)}

Skim milk was obtained by separating of cream with the help of a cream separator. Before preparing dahi from whole milk, skim milk, reconstituted milk and recombined milk, initial chemical qualities of whole milk, skim milk, whole milk powder and skim milk powder were measured. Parameters were acidity content $(\%)$, specific gravity, fat content $(\mathrm{g} / \mathrm{kg})$ total solids content $(\mathrm{g} / \mathrm{kg})$ and protein content $(\mathrm{g} / \mathrm{kg})$. Total solids (TS) contents of the milk samples were determined according to AOAC (1982). Specific gravity, fat per cent and acidity were determined using the procedure of Aggarwala and Sharma (1961). Protein was determined by Kjeldahal procedure (AOAC, 1982).

\section{Chemical analyses (Dahi)}

Immediately after the organoleptic evaluation all dahi samples were chemically analysed in the laboratory. Parameters were acidity content $(\%)$, dry matter content $(\mathrm{g} / \mathrm{kg})$, fat content $(\mathrm{g} / \mathrm{kg})$, protein content $(\mathrm{g} / \mathrm{kg})$ and ash content $(\mathrm{g} / \mathrm{kg})$. Determination procedures were same followed for chemical analyses of milk according to procedures suggested by Aggarwala and Sharma (1961).

\section{Microbiological tests}

Dahi sample were tested for:
a) Total viable count
b) b) Yeast count and
c) c) Molds count

For total viable counts of different dahi samples, Standard Plate Count (SPC) were done according to 'Standard Methods for Examination of Dairy Products' (American Public Health Association, 1967). Yeast and mold count of different dahi samples were also done according to "Standard Methods for Examination of Dairy Products' (American Public Health Association, 1967).

\section{Statistical analysis}

All experimental materials were completely homogenous and the statistical analysis was done by using Completely Randomized Design (CRD). The Statistical software packages MSTATC was carried out to determine the significant difference.

\section{Results and Discussion}

The results of chemical analyses (Acidity, specific gravity, fat, total solids, and protein) of different types of milk are shown in Table 1.

\section{Acidity (\%)}

The percentage of acidity of different milk samples were $0.16,0.16,0.21$ and 0.18 respectively (Table 1 ) . Significant difference was found $(\mathrm{P}<0.01)$. It Was found that the acidity development in sample $\mathrm{C}$ was the highest followed by sample $\mathrm{D}$ and the lowest acidity was found in samples A and B. Acidity development in reconstituted and recombined milk was higher. Acidity rapidly develops in reconstituted and recombined milk because the lactic acid producing bacteria grows well in these two medium due to easy access to lactose but all the samples have the acidity bellow $1 \%$ as was demonstrated by Castaneda et al. (1991). 
Table 1 : Comparison of average chemical composition of different types of milk

\begin{tabular}{|l|c|c|c|c|c|c|}
\hline $\begin{array}{l}\text { Chemical } \\
\text { parameter }\end{array}$ & Whole milk & $\begin{array}{c}\text { Recombined with fresh } \\
\text { skim milk }\end{array}$ & Reconstituted milk & $\begin{array}{c}\text { Recombined with skim } \\
\text { milk powder }\end{array}$ & $\begin{array}{c}\text { LSD } \\
\text { value }\end{array}$ & $\begin{array}{c}\text { Sig. } \\
\text { level }\end{array}$ \\
\hline Acidity $(\%)$ & $1.6^{\mathrm{c}} \pm 0.01$ & $1.6^{\mathrm{c}} \pm 0.00$ & $0.21^{\mathrm{a}} \pm 0.03$ & $0.18^{\mathrm{b}} \pm 0.01$ & 0.018 & $*$ \\
\hline Specific gravity & $1.03^{\mathrm{a}} \pm 0.00$ & $1.03^{\mathrm{a}} \pm 0.00$ & $1.04^{\mathrm{b}} \pm 0.01$ & $1.03^{\mathrm{a}} \pm 0.01$ & 0.020 & $*$ \\
\hline Fat $(\mathrm{g} / \mathrm{kg})$ & $44.0^{\mathrm{a}} \pm 1.00$ & $34.00^{\mathrm{b}} \pm 1.00$ & $42.33^{\mathrm{a}} \pm 1.53$ & $35.33^{\mathrm{b}} \pm 0.58$ & 2.034 & $* *$ \\
\hline Total solids $(\mathrm{g} / \mathrm{kg})$ & $117.00^{\mathrm{b}} \pm 1.0$ & $120.66^{\mathrm{b}} \pm 1.53$ & $132.33^{\mathrm{a}} \pm 3.79$ & $135.66^{\mathrm{a}} \pm 2.08$ & 4.416 & $* *$ \\
\hline Protein $(\mathrm{g} / \mathrm{kg})$ & $32.00 \pm 1.73$ & $34.00 \pm 2.00$ & $34.66 \pm 0.58$ & $33.00 \pm 1.00$ & - & $\mathrm{NS}$ \\
\hline
\end{tabular}

$*=\mathrm{P}<0.05, * *=\mathrm{P}<0.01, \mathrm{NS}=\mathrm{Not}$ significant

\section{Specific gravity}

The specific gravity of different milk samples were $1.03 \pm 0.00, \quad 1.03 \pm 0.00, \quad 1.04 \pm 0.01$ and $1.03 \pm 0.01$ respectively. There was a significant difference in specific gravity of different milk samples (Table 1). All the samples have the similar specific gravity because they are standardized to be the same composition. Generally the specific gravity of fresh cow milk is with the range of 1.027 to 1.035 having an average value of 1.032 (Eckles, 1951). Adulteration of milk by adding water decreases its specific gravity. Comparatively specific gravity of reconstituted milk is highest than others.

Fat $(\boldsymbol{g} / \mathrm{kg})$

The fat content of different milk samples were 44.0, $34.0, \quad 42.33$ and 35.33 respectively. Statistical analysis showed that there was a significant difference (Table 1). Sample a was the higher fat percentage than others. The values of average percentage of fat content of cow milk samples agreed with the report of Ghaatak et al. (1989) and Biswas (1997) whom found that average percentage of fat content of cow milk samples were 3.97 and $3.7 \pm 0.72$ respectively.

\section{Total solids $(\mathrm{g} / \mathrm{kg})$}

The total solids content of different milk samples were $117.00 \pm 1.00,120.66 \pm 1.53,132.33 \pm 3.79$ and $135.66 \pm 2.08$ respectively. There was a significant difference in total solids of milk samples (Table 1). All the samples have almost the similar. Total solid $(\mathrm{g} / \mathrm{kg})$ because they are standardized to be the same composition this results also aggress with the work of Younsh (1998).

\section{Protein $(\mathrm{g} / \mathrm{kg})$}

The protein content of different type of milk samples were $32.0,34.0,34.66$ and 33.0 respectively. Table 1 show the protein content of whole milk, skim milk, reconstituted and recombined milk, there were non significant difference within the protein content of the different types of milk. Chatak et al. (1989) found that percentage of mean protein content of cow milk samples was 3.35. In our experiment, percentage of protein content was as like as similar. So it is acceptable.

\section{Physical parameters}

The scores for smell and taste, body and consistency, color and texture and overall scores are obtained given in the Table 2 .

\section{Smell and taste}

Smell and taste score of dahi samples were $46.50 \pm 0.58,43.75 \pm 0.50,41.50 \pm 3.11$ and $43.25 \pm 0.96$ respectively. Statistical analysis shows that, there was a significant difference among the smell and taste scores of different dahi samples (Table 2). Smell and taste score of the whole milk dahi ranked the highest followed by recombined with fresh skim milk dahi, whereas reconstituted milk dahi and recombined with skim milk powder dahi were relatively inferior in quality. The smell and taste of dahi are largely dependent on the condition of raw materials used, especially the milk. Dahi prepared from whole milk bears the full aroma and flavour. But when the milk is skimmed, a vital flavouring compound, the milk fat, is lost.

Moreover, milk that has experienced a powdering process acquires a distinct flavour of powder milk transmitting this smell and taste to products manufactured from it. That's why dahi made from reconstituted and recombined milk have a different taste than the whole milk dahi. The consumers are yet to be accustomed to this new flavor. Foster $e t$ al. (1958) evaluated that sensory properties and volatile aroma compounds in yogurts prepared using various proportions of whole milk, skim milk, reconstituted and recombined milk. Yogurt containing a heavy consistency resembling custard, ideally the curd should be smooth and firm.

\section{Body and consistency}

The body and consistency scores of different dahi samples were $27.00 \pm 0.00,25.25 \pm 0.96,24.00 \pm 1.83$ and $25.00 \pm 1.41$ respectively (Table 2 ). Significant difference $(p<0.05)$ was found for body and consistency scores of different dahi samples. The body and consistency score was highest for whole milk dahi and recombined with fresh skim milk dahi. Reconstituted milk dahi and recombined with skim milk powder dahi obtained slightly low scores. So, it is better to add more powdered milk to prepare reconstituted and recombined milk which are to be 
prepared to make dahi. Pette and Lolkema (1950) attribute Streptococcus thermophilus to improve the body of yogurt by reducing the viscosity characteristics of milk cultures of Lactobacillus bulgaricus. The variation of body consistency scores among different samples might be due to adding of powdered milk.

Table 2. Comparison of average score of various organoleptic characteristics of different types of milk dahi (physical tests)

\begin{tabular}{|c|c|c|c|c|c|c|}
\hline Physical parameter & Whole milk dahi & $\begin{array}{l}\text { Recombined with } \\
\text { fresh } \\
\text { skim milk dahi }\end{array}$ & $\begin{array}{l}\text { Reconstituted } \\
\text { milk dahi }\end{array}$ & $\begin{array}{l}\text { Recombined with } \\
\text { skim } \\
\text { milk powder dahi } \\
\text { powder dah }\end{array}$ & $\begin{array}{l}\text { LSD } \\
\text { value }\end{array}$ & $\begin{array}{l}\text { Sig. } \\
\text { Level }\end{array}$ \\
\hline Smell and taste & $46.5 \mathrm{o}^{\mathrm{a}} \pm 0.58$ & $43.75^{b} \pm 0.50$ & $041.50^{\mathrm{b}} \pm 0.03$ & $43.25^{b} \pm 0.01$ & 2.725 & $*$ \\
\hline Body and consistency & $27.00^{\mathrm{a}} \pm 0.00$ & $25.25^{\mathrm{ab}} \pm 0.96$ & $24.00^{\mathrm{b}} \pm 1.83$ & $25.00^{\mathrm{ab}} \pm 1.41$ & 2.039 & $*$ \\
\hline Colour and texture & $17.75^{\mathrm{a}} \pm 0.29$ & $16.25^{\mathrm{ab}} \pm 1.26$ & $15 . .75^{\mathrm{b}} \pm 1.26$ & $15.75^{\mathrm{b}} \pm 0.50$ & 1.525 & $*$ \\
\hline Overall final score & $91.25^{\mathrm{a}} \pm 1.50$ & $85.50^{\mathrm{b}} \pm 0.58$ & $81.25^{\mathrm{c}} \pm 8.85$ & $84.00^{b c} \pm 2.08$ & 3.745 & $* *$ \\
\hline
\end{tabular}

$*=\mathrm{P}<0.05, * *=\mathrm{P}<0.01$

\section{Colour and texture}

The colour and texture scores of whole milk dahi, recombined with fresh skim milk dahi, reconstituted milk dahi and recombined with skim milk powder dahi were $17.75 \pm 0.29,16.25 \pm 1.26,15.75 \pm 1.26$ and $15.75 \pm 0.50$ respectively, significant difference $(\mathrm{P}<0.05)$ was found (Table 2). The colour and texture scores were highest in whole milk dahi and lowest in recombined with skim milk powder dahi. Recombined with fresh skim milk dahi and reconstituted milk dahi ranked medium. Colour of dahi prepared from whole milk is rich due to its rich cream layer and rapid caramalization during heating. But, in case of recombined milk the coagulum is weak and white, which may be improved by adding more milk powder and prolonged heating. Ranganadham and Gupta (1987) evaluated the sensory characteristics of dahi recommended that colour of dahi sometimes depends on the type and condition of container.

\section{Overall score}

The overall scores of various types of dahi were determined by accumulating the scores recorded for different sensory attributes and the results were presented in Table 2. Significant difference $(\mathrm{P}<0.01)$ was found in respect of orerall score of whole milk, skim milk, reconstituted and recombined milk dahi which were $91.25 \pm 1.50,45.50 \pm 0.58,81.25 \pm 8.85$ and $84.00 \pm 0.82$ respectively. The overall scores were high in whole milk dahi and recombined with fresh skim milk dahi samples and lower in reconstituted milk dahi and recombined with skim milk powder dahi. The results of this are more similar with the work of Gosh and Rajorhia (1987) and Sarkar et al. (1996).

\section{Chemical parameters \\ Acidity (\%)}

The percentage of acidity of different dahi samples A, B, C and D were 0.71, 0.68, 0.76 and 0.83 respectively (Table 3 ). Significant difference was found $(\mathrm{P}<0.01)$. It was found that the acidity development in sample $\mathrm{D}$ was the highest followed by sample $\mathrm{C}$ and the lowest acidity was found in sample B. Acidity development in recombined and reconstituted milk dahi was higher because the lactic acid producing bacteria grows well in these two medium due to easy access to lactose. But all the samples have the acidity below $1 \%$ as was demonstrated by Castaneda et al. (1991). So, all the samples are acceptable.

\section{Dry matter $(\mathrm{g} / \mathrm{kg})$}

The dry matter content of different dahi samples were $389.00 \pm 48.88,386.00 \pm 10.54,403.66 \pm 5.51$ and 409.00 \pm 5.00 respectively. There was a nonsignificant difference in dry matter content of different dahi samples (Table 3). All the samples have almost the similar percentage of DM because they are standardized to be the same composition. This result also agrees with the work of Younus (1998).

\section{Fat (g/kg)}

Fat content of different dahi samples were 59.33, $52.33,53.33$ and 49.00 respectively. Statistical analysis showed that there was a non-significant difference (Table 3). All the samples were the same percentage of fat because heavy cream $(50 \%$ butter fat) was added to skim milk and recombined milk to balance the fat percentage in comparison with the whole milk and reconstituted milk. Sarkar et al. (1996) reported that the fat per cent of plain dahi from different areas of West Bengal ranged from 1.1 to 11.5 per cent with an average of 5.14. 
Table 3. Comparison of average chemical composition and microbiological status of different types of milk dahi

\begin{tabular}{|c|c|c|c|c|c|c|c|}
\hline \multicolumn{2}{|c|}{ Parameter } & $\begin{array}{l}\text { Whole milk } \\
\text { dahi }\end{array}$ & $\begin{array}{l}\text { Recombined with } \\
\text { fresh skim milk dahi }\end{array}$ & $\begin{array}{l}\text { Reconstituted } \\
\text { milk dahi }\end{array}$ & $\begin{array}{l}\text { Recombined } \\
\text { with skim milk } \\
\text { powder dahi }\end{array}$ & $\begin{array}{l}\text { LSD } \\
\text { value }\end{array}$ & $\begin{array}{l}\text { Sig. } \\
\text { level }\end{array}$ \\
\hline \multicolumn{2}{|c|}{ Acidity (\%) } & $0.71^{\mathrm{bc}} \pm 0.03$ & $0.68^{\mathrm{c}} \pm 0.03$ & $0.76^{\mathrm{b}} \pm 0.03$ & $0.83^{\mathrm{a}} \pm 0.03$ & 0.059 & $* *$ \\
\hline \multicolumn{2}{|c|}{ DM $(\mathrm{g} / \mathrm{kg})$} & $389 \pm 48.88$ & $386.00 \pm 10.54$ & $403.66 \pm 5.51$ & $409.00 \pm 5.00$ & - & NS \\
\hline \multicolumn{2}{|c|}{ Fat $(\mathrm{g} / \mathrm{kg})$} & $59.33 \pm 11.06$ & $52.33 \pm 0.58$ & $53.33 \pm 1.15$ & $49.00 \pm 1.00$ & - & NS \\
\hline \multicolumn{2}{|c|}{ Protein $(\mathrm{g} / \mathrm{kg})$} & $52.00 \pm 17.00$ & $53.33 \pm 2.52$ & $53.66 \pm 1.53$ & $53.66 \pm 0.58$ & - & NS \\
\hline \multicolumn{2}{|c|}{$\operatorname{Ash}(\mathrm{g} / \mathrm{kg})$} & $18.00 \pm 6.00$ & $19.00 \pm 1.00$ & $20.00 \pm 1.00$ & $20.66 \pm 1.53$ & - & NS \\
\hline \multirow{2}{*}{$\begin{array}{l}\text { Total viable } \\
\text { count }\end{array}$} & Count $/ \mathrm{ml}$ & $49 \times 10^{4}$ & $43 \times 10^{4}$ & $46 \times 10^{4}$ & $52 \times 10^{4}$ & \multirow{2}{*}{0.022} & \multirow[t]{2}{*}{$*$} \\
\hline & Log value & $5.67^{\mathrm{b}} \pm 0.02$ & $5.63^{\mathrm{c}} \pm 0.01$ & $5.65^{\mathrm{bc}} \pm 0.04$ & $5.70^{\mathrm{a}} \pm 0.01$ & & \\
\hline \multirow{2}{*}{ Yeast count } & Count $/ \mathrm{ml}$ & 5 & 6 & 11 & 14 & \multirow[b]{2}{*}{0.084} & \multirow{2}{*}{$* *$} \\
\hline & Log value & $0.69^{\mathrm{a}} \pm 0.00$ & $0.83^{\mathrm{c}} \pm 0.07$ & $0.99^{\mathrm{b}} \pm 0.05$ & $1.17^{\mathrm{a}} \pm 0.04$ & & \\
\hline \multirow{2}{*}{ Mold count } & Count $/ \mathrm{ml}$ & 5 & 7 & 13 & 10 & \multirow{2}{*}{0.103} & \multirow{2}{*}{$* *$} \\
\hline & Log value & $0.71^{\mathrm{b}} \pm 0.05$ & $0.81^{\mathrm{b}} \pm 0.08$ & $1.06^{\mathrm{a}} \pm 0.04$ & $0.98^{\mathrm{a}} \pm 0.03$ & & \\
\hline
\end{tabular}

$*=\mathrm{P}<0.05, * *=\mathrm{P}<0.01, \mathrm{NS}=\mathrm{Not}$ significant

\section{Protein $(\mathrm{g} / \mathrm{kg})$}

Protein content of different types of dahi samples were 52.0, 53.33, 53.66 and 53.66 respectively (Table 3). There were non-significant differences within the protein content of the different types of dahi. The result was almost similar to the work of Castaneda et al. (1991) who found $4.68 \%$ protein in yogurt.

\section{Ash ( $\mathrm{g} / \mathrm{kg})$}

Ash content of different types of dahi samples were $18.00,19.00,20.00$, and 20.66 respectively (Table $3)$. The ash content of different dahi samples was almost similar and there was a non-significant difference as the statistical analysis has revealed. In good quality dahi, ash content ranges from $14-20 \mathrm{~g}$ per $\mathrm{kg}$ as the milk is concentrated by reduction of volume to $60-70 \%$ by boiling and also from sugar some mineral matter is also imported. So, all the samples are normal in their ash content. The results of this study agree with the work of Mustafa (1997), Rahaman (1998) and Alam (1998) because they found similar result.

\section{Microbiological analysis}

The results of microbiological analyses are shown in Table 3.

\section{Total viable bacterial count (TVC)}

In this experiment it was observed that the total viable count of samples were 5.67, 5.63, 5.65 and 5.70 respectively (Table 3 ). Statistical analysis showed that TVC of different dahi samples differ significantly $(\mathrm{p}<0.05)$. Highest number of bacteria was found in recombined with skim milk powder dahi sample and lowest was found in recombined with fresh skim milk dahi sample. It is generally observed that lactic acid producing bacteria multiplicates rapidly in reconstituted/recombined milk may be due to easy availability of lactose than from whole milk. The results of this parameter agree with that of the result of Murtaza (1998).

\section{Yeast count}

Yeast counts of various samples were $0.69,0.83$, 0.99 and 1.17 respectively. Significant difference $(\mathrm{p}<0.01)$ was found among the yeast content of different types of dahi samples. Reconstituted milk dahi and recombined with skim milk powder dahi samples have higher yeast count may be due to the presence of yeast spores in the milk powder.

\section{Mould count}

Mold content of different dahi samples were 0.71, $0.81, \quad 1.06$ and 0.98 respectively (Table 3 ). Significant difference $(\mathrm{p}<0.01)$ was found among the mold contents of different types of dahi samples. In reconstituted milk dahi and recombined with skim milk powder dahi samples were high in mold counts may be due to mold cells were present in the powdered milk. Molds generally grow in powdered milk than in fluid milk. This organism also grows in dahi during prolonged storage. But in this experiment, dahi was not stored for long time, rather was consumed readily. So, there was spore for mold cell development during storage. Therefore, the high mold count should be attributed to the mold cells present in milk powders those are used to prepare the reconstituted and recombined milk. Results in the present investigation do not exceed the range of yeast and mold count those report of Murtaza (1998). A calculation of production cost was carried out during the preparation of different types of dahi (production cost of per kg whole milk dahi, skim milk dahi, reconstituted milk dahi and recombined milk dahi were Tk. 39.00, 33.00, 32.00 and 29.00 respectively) and it was found that the cost of production for the recombined milk dahi and reconstituted milk dahi was not more than the other two types, rather recombined milk dahi was cheapest to manufacture.

\section{Conclusion}

Whole milk is scarce in our country. Even skim milk is also not readily available. But we import huge amount of powdered whole milk and skim milk 
every year, which is used in our sweetmeat industry. So the findings of this study could be very helpful in this regard, though more experiments are needed. This research work reveals clearly that acceptable

\section{References}

Aggarwala, A. C. and Sharma, R. M. 1961. A Laboratory Manual of Milk Inspection. Bombay, Calcutta, New Delhi, India.

Akter, N.; Nahar, A.; Islam, M. N. and Al-Amin, M. 2010. Effect of different level of starter culture and sugar on manufacturing characteristics of Misti Dahi (Sweet Yoghurt). J. Bangladesh Agril. Univ., 8(2):245-252.

Alam, M. S. 1998. A study on the preparation of dahi from soya milk. M.S. thesis, Dept. of Dairy Science. 34p.

APHA. 1998. Standard Methods for Examination of Dairy Products. 20th Edn., American Public Health Association, Washington, DC., USA.

AOAC. 2002. Official Methods of Analysis. 17th Edn., Association of Analytical Chemists, Gaithersburg, MD., USA.

Biswas, A. A. 1997. Effect of banana (Musa sapientum) leaf on the keeping quality of raw milk. M.S. Thesis, Department of Dairy Science, Bangladesh Agricultural University, Mymensingh, Bangladesh.

Castandeda, F. C.; De Hombre M. R. and Rajas, C. I. 1991. Effect of heat treatment as firmness of yogurt made from buffalo milk. Revista Cubana de Alimentaciony Nutrition, 5(2): 114- 117. [CABED Abst. 193-94].

Chakraborty, M. 1998. A study on the preparation of dahi from whole milk of cow, buffalo and their different proportionate mixtures. MS thesis, Dept. of Dairy Science, Bangladesh Agricultural University, Mymensingh, Bangladesh. Dairy Management \& Milk Products: DMMPS14 (Special Milks, Booklet No. 284).

Eckles, C. H.; Combs, H. B.; Macy, H. 1951. Milk and milk products. $4^{\text {th }}$ Edn. McGraw-Hill Book Company, New York, Toronto, London, 48p.

Foster, E. M.; Nelson, F. E.; Spech, M. I.; Doetsch, R. M. and Olson, J. C. 1958. Dairy Microbiology. Macmillan and company limited, New York. 327p. quality dahi can easily be made from reconstituted and recombined milk.

Ghatak, P. K.; Bandyopadhay, A. K. and Gupta, M. P.1989. The relation between the heat stability of milk and its chemical composition. Asian J. Dairy Res., 8(3): 165-168.

Gosh, J. and Rajorhia, G. S. 1987. Chemical, Microbiological and Sensory properties of misti dahi sold in Calcutta. Asian J. Dairy Res., 6(1): 11-16.

Murtaza, A. F. M. 1998. Studies of the Physical, Chemical and Microbiological qualities of misti dahi of the different districts of Bangladesh. M.S. thesis, Dept. of Dairy Science, Bangladesh Agricultural University, Mymensingh, Bangladesh.

Mustafa, M. M. H. 1997. A study on the preparation of fruit dahi (yogurt). M.S. thesis, Dept. of Dairy Science, Bangladesh Agricultural University, Mymensingh, Bangladesh.

Nahar, L. 2000. Studies on the preparation of dahi (yougurt). M.S. Thesis. Dept. of Dairy Science, Bangladesh Agricultural University, Mymensingh, Bangladesh.

Pette, J. W.; Lokema, H. 1950. Yogurt. I. Symbiosis and antibiosis of mixed cultures of Lactobacillus bulgaricus and Strptococcus thermophilus. Neth. Milk Dairy J., 4(3): 197- 208. [Dairy Sci. Abst. 14: 350]

Rahman, S. M. 1998. A study on the manufacture and shelf life of Jackfruit dahi (yogurt). $M S$ Thesis, Dept. of Dairy Science., Bangladesh Agricultural University, Mymensingh, Bangladesh.

Ranganadham, M.; Gupta, S. K. 1987. Sensory evaluation of dahi and yogurt. Indian Dairy Man., 39(10): 493-497.

Sarkar, S.; Kuila, R. K. and Misra, A. K. 1996. Organoleptic, Micobiological and Chemical quality of misti dahi sold in different districts of West Bengal. Indian J. of Dairy Sci.,49 (1):54- 61[CABED,Abst.: 1996-97].

Stocklin, P. 1969. Cul. Dairy Production. J., 46:6

Younus 1998. A comparative study on the quality of dahi (Yogurt) available in Mymensingh Town. M. S. Thesis, Department of Dairy Science. Bangladesh Agricultural University, Mymensingh, Bangladesh. 